\title{
To Forget Murder Victims is to Kill Them Twice: The Prospect of Teaching "The Holocaust" in Jordan
}

Majid Salem Mgamis*

English Department, Tafila echnical University, P.O Box 179 - Tafila, 6610 - Jordan

Corresponding Author: Majid Salem Mgamis, E-mail: esotericities@yahoo.co.uk

\section{ARTICLE INFO}

Article history

Received: June 07, 2017

Accepted: September 01, 2017

Published: October 31, 2017

Volume: 8 Issue: 5

Advance access: October 2017

Conflicts of interest: Non

Funding: None

\begin{abstract}
This paper examines the possibility of teaching the holocaust in Jordanian universities. In this regard, it highlights the socio-religious challenges that may impede such a project and suggests some methods to overcome them. It discusses the material to be taught and the background that should be furnished for students before presenting the topic. The paper draws on academic as well as political sources to enrich the project it proposes.
\end{abstract}

\author{
Key words: \\ Holocaust, \\ Pedagogy, \\ Teaching literature, \\ The Other, \\ Jewish Literature
}

\section{INTRODUCTION}

\section{Research Problem}

The history of Arab-Israeli relations has witnessed constant conflicts for centuries. Two major ideas should be mentioned in this regard. The conflicts have been political rather than religious; in more particular terms, the struggle focuses on the issue of possessing the land rather than supremacy of religion. Second, there is confusion among Arabs between the concepts of "Israeli" and "Jew;" thus mixing the political with the religious. The bottom line is that this conflict is dominant so much so that it affects all disciplines and institutions.

One of the major fields which has been influenced by such political considerations is the educational one. In this regard, although there have been humble attempts to include the topic in the curriculum, teaching the Holocaust has almost been banned, though sometimes unconsciously, in all Arab countries, viewing it as "fairytale serving Zionist propaganda" (Freidman). Like most Arab counterparts, the Jordanian educational system has been inflicted with the banking model of education. This model, proposed by the Brazilian Pedagogue, Paulo Freire, highlights the existence of a single authority that others have to follow; rejecting any form of democracy or freedom of thinking. This autocratic pedagogical ideology has banned teaching the Holocaust in the country. On the other hand, critical pedagogy as model of education, goes in stark contrast with the despotic banking system. The critical pedagogy model is based on democracy, emancipation, empowerment of students as well as freedom of thinking. In line with this liberal model, the educational arena should not be influenced by any political or religious agenda resulting in preventing any mentioning of the Holocaust in teaching (Freire).

\section{Research Objective}

This paper intends to address the possibility of introducing the Holocaust for undergraduate students in my home country; Jordan. The focal concern will be on two primary challenges in the process of teaching the holocaust. First, how to convince students and/or the pedagogical authority of the necessity and significance of addressing the topic; second, how to maintain a neutral critical analysis of the topic in the midst of the tremendous antagonistic stand towards the Jews. Evidently, attempting this challenging project is not an easy task. Taking the aforementioned political situation in the country, it becomes a great adventure. 


\section{DISCUSSION}

The first challenge in conducting this project would be to design a well-crafted method to make the topic acceptable to students. To begin with, there should be some clarific tion of the Jew/Israeli confusion so that students do not mix the political with the religious. In more particular terms, students should understand that the victims of the Holocaust are the ancestors of the Israelis they have problem with now. They were holders of the Jewish religion rather than a certain political agenda. In this regard, as people in my culture are mostly moved by religious dictates, I will back up this introduction for this topic by providing a view on how teaching the Holocaust does not go against the religious teaching, but rather conforms to these teachings.

First, I will present the positive view of Jews in Islam and how Islam has praised the Jews in more than one instance in the Quran. In addition, I would highlight the benign treatment of the Jews by Prophet Mohammad as he always stressed that Muslims should be nice to the Jews as both individuals as well as communities. Moreover, I would stress that Islam has rejected any form of oppression practiced against any people of any religion or nationality. I would enhance this theoretical frame by practical examples from the Muslim history. I would mention how the prominent Khalif, Omar, after taking Jerusalem from Byzantium, allowed the Jews to reestablish their community in the city and practice their religion freely. I would also show how Salah-al-Din, the great Muslim leader, did the same in the $12^{\text {th }}$ century (Friedman). Other Islamic teachings and historical examples that contribute to this issue will also be highlighted.

This introductory framework would necessarily establish a solid ground for introducing the Holocaust to the students. The next step would be to stress that although it is the Jews who were targeted more specifically by the Nazi regime, Hitler's massacres and oppressions were not restricted to the Jews. I would mention other groups of victims such as the physically disabled, the homosexuals, the Jehova Witnesses and the Soviet prisoners of war. This would enhance the idea that there was nothing essentially "wrong" with the Jews that made Hitler target them by his hegemonic power. Rather, his oppression of the Jews was part of his "master Aryan ideology" that targeted other groups of people who, for him, did not deserve to live.

In this respect, the reference to the relationship between Darwinism and Nazism might prove to be very fruitful. Many writers, such as Richard Weikart, have highlighted the existence of a Darwinian influence on Hitler. Although Weikart admits that "Darwinism by itself did not produce the Holocaust," he goes on to stress that "without Darwinism, especially in its social Darwinist and eugenics permutations, neither Hitler nor his Nazi followers would have had the necessary scientific underpinnings to convince themselves and their collaborators that one of the world's greatest atrocities was really morally praiseworthy" (233). This linking between Darwinism and the autocracy of Hitler would highlight the abominable acts of Hitler against the Jews in the minds of the students. Muslims have always been against the theory of evolution; hence, realizing that Hitler was, at least unconsciously, an advocate of this school of thinking would probably increase students' indignation of Hitler and their eagerness to know the details about his victims' suffering.

I would say that such an introduction to the course is worth one third of the syllabus, at least in the first attempts (years) of teaching this course. This aims at establishing a solid ground for the topic that would gives more credence for its adoption. Later on, this framework may be minimized to include more pertinent Holocaust material.

In addressing the Holocaust literature as such, I would prefer first giving students a chronological overview of the Holocaust. This is very important especially for undergraduate students in Jordan since most of the information they have about the Holocaust is out of context. In addition, putting the Holocaust crimes in the context of the Second World War would give the topic more credence and attract the students to its details. I believe that Jordanian students will be interested in material about the ghettos so much. This is because of it resemblance of the situation they lived in the past. As a background to this material, I would include material from The Old Testament as it constitutes important reference contributing to clarification and understanding of primary sources

Equally important, students will be referred to the USHMM website (United States Holocaust Memorial Museum), not only to gain knowledge of written documents about the Holocust, but also to see photos and videos of the Nazi crimes. For future reference, I would give a proposal to the university administration to allow for educational visits to USHMM for distinguished students. If approved, this would increase the enthusiasm of the students to enroll in the course and take it more seriously. Most importantly, in order to improve the quality of the course over time, I would ask students to anonymously write their feedback about the material, the workload, the performance of the instructor and any notes they would like to add. This would help develop better teaching methods for this topic.

I fully realize that this methodology will not be without obstacles; however, I am determined to face all challenges as far as I am contributing to enriching knowledge, enhancing acceptance of "The Other" and giving due respect to victims of oppression and autocracy. If this process works out and the Holocaust is established as a full-fledged topic in the university, there are other issues which, I believe, are worth considering in teaching the Holocaust per se. One of these is the challenging issue of practicing neutral critical analysis of the Holocaust literature despite the collective consciousness regarding the Jews.

This issue is so pertinent to the Holocaust literature as the material may well entice negative emotions in the mind of the reader. Students will be emotionally attached to the texts; not only because there is a conflict between "affect" and "analysis" (Slovic et.al), but because of the historical conflict with the Jews. Thus, before addressing the ability to combine reason and emotion in dealing with the texts, and taking the aforementioned Arab-Israeli political conflict, one has to approach the issue of the probability of emotional repercussions on the part of Arab students in the first place

Gail Berlin addresses this issue in her essay entitled "Once there was El'zunia": Approaching Affect in Holocaust 
Literature." Taking El'zunia poem as an example, the author argues "for a reconsideration of interpretive approaches to Holocaust literature and other literatures of trauma and a frank acknowledgement of the emotional complexity that these texts generate, in and of themselves and within the pedagogical situation" (397). She is quick to note that "the tools we possess are not well calibrated for literature of the extreme" (398) and thus proposes a methodology to integrate both compassion and critical analysis in approaching Holocaust texts.

Drawing on Berlin's thesis, my approach will be directed towards involving the students in the events being studied rather than choosing "certain texts that have the advantage of distancing the reader from events" (Berlin 399). I will depend on the psychological differentiation between identification, empathy and compassion as suggested by Berlin to increase the possibility of the student's compassion with the victims. Berlin quotes Martha Nussbaum's explication of the three requirements of compassion:"The first [...] is a belief or appraisal that the suffering [of another person] is serious rather than trivial. The second is the belief that the person does not deserve the suffering. The third is the belief that the possibilities of the person who experiences the emotion are similar to those of the sufferer" (qtd in Berlin 400).

To what extent are these requirements met in the Jordanian universities setting? I would argue that the first and third requirements are met in these students' case. They will realize the seriousness of the victims' suffering. They will also be thinking about the similar possibilities of the experiences, drawing on the current Palestinians' problem with Israel. In fact, commenting on the Arab stand regarding the Holocaust, Essam al-Arian, a famous Arab politician and a former member of the Guidance Bureau of the Muslim Brotherhood, once said: "one cannot deny the holocaust of the Jews or of other peoples" (Friedman). What he meant by the "other peoples" here is the Palestinians.

There is a wide popularity of the term "Palestinian Holocaust." The Palestinian Holocaust Museum (PHM) has strengthened this view quoting Israel's deputy defense minister Matan Vilnai, Who said: they [the Palestinians] will bring upon themselves a bigger 'shoah' [a Hebrew word for catastrophe and a synonym for the Nazi Holocaust] because we will use all our might to defend ourselves" (PHM). Rashad Abu Shawar also claims that "...the Palestinian holocaust targets not only human beings but also land, trees, heritage and civilization ... the Palestinian holocaust did not end with the 1948 war, or the 1967 war,... the Zionist genocide scheme ... and displacement policies are still very much in effect - and will stay that way until the Palestinians are completely and definitively uprooted from the land of their ancestors - the Palestinian holocaust could only be described as 'ongoing"" (The National).

This background would give a sense of similarity of experience in the students during teaching and thus would add to the feeling of compassion with the victims. However, considering the second requirement suggested by Nussbaum, one would surely doubt as to what extent the students would feel that the victims do not deserve the victimhood they were exposed to. The historical enmity between the two cultures may create in the minds of students some justification for the misery. Still, the introduction for the course would play a vital role in neutralizing the feelings of the students so that they approach the topic without any pre-conceived and socially constructed agenda. This would help in creating more compassion during the process of learning. In order to further this engagement, students will be asked to express their emotion through keeping a poetry journal. Students will not be evaluated for the quality of their poems since the intent will be to enrich their emotional involvement and expression.

\section{CONCLUSION}

To conclude, this research attempts at providing a blueprint for teaching the Holocaust in Jordanian Universities. It shows how the project of introducing the Holocaust to Jordanian undergraduate students is essentially challenging. Such a challenging project entails facing the strong political and institutional agenda that would strongly oppose the idea. This requires adopting a methodology that would make the venture possible and convincing. In the process of teaching the Holocaust, one of the major concerns will be how to emotionally engage the students with the material. Again, this depends on the success of the introduction. In the final analysis, there is an urgent need to introduce the students to the Holocaust and to establish "a pedagogical model of analysis" that would allow students to engage in the texts "to the limited extent possible" (Berlin 402).

\section{REFERENCES}

Berlin. G. (2012). “Once there was El'zunia: Approaching Affect in Holocaust Literature." College English, Volume 74, Number 5, May 2012. http://www.ncte.org/ journals/ce/issues/v74-5 retrieved June $7^{\text {th }}, 2012$.

Freire, P. (1984). Pedagogy of the oppressed. New York: Continuum Publishing Corporation.

Friedman, Yaron. (2012) "Shoah in the Arab World: Op-ed: How prevalent are Holocaust denial, anti-Jewish propaganda in Arab and Muslim world?" Published: 04.20.12 Israeli Opinion. http://www.ynetnews.com/articles/0,7340,L-4218661,00.html. Retrieved, June $1^{\text {st }}$. 2012. Web.

The National.n (2012) “A Palestinian Holocaust.” Jan 20, 2012. http://www.thenational.ae/thenationalconversation/comment/a-palestinian-holocaust retrieved June $8^{\text {th }}$, 2012. Web.

Palestinian Holocaust Museum. (2012) http://palestinianholocaust.net/English/In_Depth/GazaHolocaustMuseum/ index.shtml Retrieved June $8^{\text {th }}, 2012$. Web.

Slovic P, Finucane ML, Peters E, MacGregor DG. (2004). "Risk as Analysis and Risk as Feelings: Some Thoughts about Affect, Reason, Risk, and Rationality." Risk Analysis. 2004;24:311-322. Print.

Weikart, R. (2004). From Darwin to Hitler: Evolutionary Ethics, Eugenics, and Racism in Germany. New York: Palgrave Macmillan, 2004. Print. 